\title{
Applying the National and International Standards of Quality Assurance within Higher Education
}

\author{
Mhd Isam Hasan Agha ${ }^{1}$, Ramah Baaj ${ }^{2}$ \\ ${ }^{1}$ Prof. Faculty of Pharmacy- SPU \\ ${ }^{2}$ Master. Dr. Faculty of Pharmacy- SPU
}

\begin{abstract}
Introduction: Quality assurance in higher education should be the main subject of the policy of higher education in all Universities and Faculties. Of these faculties is the faculty of pharmacy. Subject: Applying the national and international policies of quality assurance in higher education; Faculty of Pharmacy -SPU Tools: Information's formulas (Questionnaire) about the subject's syllabus and learning outcome. Results: SPU has followed the main international policies of quality assurance in higher education in the Faculty of Pharmacy in booth subject syllabus and the Outcomes in general.
\end{abstract}

Keywords: Quality assurance, Higher education, Pharmacy, SPU

\section{Introduction}

Universities and Faculties should have a policy and procedures for the assurance of the quality and standards of their programs and awards.

They should also commit themselves explicitly to the development of a culture which recognizes the importance of quality, and quality assurance, in their work.

Therefore Faculties should develop and implement a strategy for the continuous enhancement of quality.

a) Information systems:

Universities and Faculties should ensure that they collect, analyze and use relevant information for the effective management of their programs of study and other activities. These information can be collected using suitable Questioners, which should be contain all main questions about Subjects, Syllabus, Learning Outcomes

b) Criteria for decisions:

Any formal decisions made as a result of an external quality assurance activityshould be based on explicit published criteria that are applied consistently. The designated Questionnaire formulas must secure and filled anonym.

c) Processes fi t for purpose:

All external quality assurance processes should be designed specifically to ensuretheir fitness to achieve the aims and objectives set for them. The designated Questionnaire formulas must secure and filled anonym.

d) Follow-up procedures:

Quality assurance processes which contain recommendations for action orwhich require a subsequent action plan, should have a predetermined follow- upprocedure which is implemented consistently, therefore each faculty must make a research to know how good the Quality of his graduate is.

e) Periodic reviews:

External quality assurance of institutions and/or programs should be undertaken on a cyclical basis. The length of the cycle and the review procedures to be used should be clearly defined and published in advance.

\section{Aim and Method}

\subsection{Aim}

Aim of this study is: assess the applying of national and international standard parameter in Higher education especially in the Faculty of Pharmacy (Education Programs and outcomes)

\subsection{Methods}

Formulas of Questioner, which must be filled from Students and Stakeholders. The Questionnaire formulas were designed and filled from 500 Students of Pharmacy and 100 different Stakeholders.

Questionnaire Formulas for quality assurance

- Questioners about the subjects syllabus

- Information's Questionnaire formulas about the subject's syllabus, learning outcome (Stakeholders) were designed as mentioned in the following.

Questionnaire formula about the Studied Subjects Syllabus in the Program of Pharmacy-SPU

\begin{tabular}{|l|l|l|l|l|l|l|l|}
\hline Item & $100 \%$ & $90 \%$ & $80 \%$ & $70 \%$ & $60 \%$ & $50 \%$ & Lower 50\% \\
\hline Is the Subjects cover all Syllabus & & & & & & & \\
\hline Is the subject Cover the requirements & & & & & & & \\
\hline Is the amount of the given information sufficient & & & & & & & \\
\hline Is the lecture long & & & & & & & \\
\hline
\end{tabular}


International Journal of Science and Research (IJSR)

ISSN (Online): 2319-7064

Index Copernicus Value (2015): 78.96 | Impact Factor (2015): 6.391

\begin{tabular}{|l|l|l|l|l|l|l|l|}
\hline Is the syllabus adequate to the Program & & & & & & & \\
\hline Modernization of the Syllabus & & & & & & & \\
\hline Is the way to give the subjects suitable & & & & & & & \\
\hline self-learning understanding the syllabus & & & & & & & \\
\hline clarity the mission of the Subject & & & & & & & \\
\hline Is the level of the Subject Suitable & & & & & & & \\
\hline Are you satisfied with your Lecturer & & & & & & & \\
\hline Are you convinced teachers & & & & & & & \\
\hline Are you convinced the college management & & & & & & & \\
\hline
\end{tabular}

Questionnaire formula about the Outcome (the graduate)

\begin{tabular}{|c|c|c|c|c|c|c|c|c|}
\hline Item & & $100 \%$ & $90 \%$ & $80 \%$ & $70 \%$ & $60 \%$ & $50 \%$ & $\begin{array}{l}\text { Less } \\
50 \%\end{array}$ \\
\hline \multirow[t]{7}{*}{ Is the levels of graduate suitable for intended job } & $\begin{array}{l}\text { Pharmaceutical } \\
\text { company }\end{array}$ & & & & & & & \\
\hline & General pharmacy & & & & & & & \\
\hline & Hospital Pharmacy & & & & & & & \\
\hline & Pharmaceutical factory & & & & & & & \\
\hline & Drug store & & & & & & & \\
\hline & University Lecturer & & & & & & & \\
\hline & $\begin{array}{l}\text { Insurance } \\
\text { Companies }\end{array}$ & & & & & & & \\
\hline \multicolumn{9}{|l|}{ Apply the Graduate the Ethics Of the Pharmacy } \\
\hline \multicolumn{9}{|l|}{ Commitment and respect the graduates to their University } \\
\hline \multicolumn{9}{|l|}{ The level of graduates in language } \\
\hline \multicolumn{9}{|l|}{$\begin{array}{l}\text { Dealing with the computer and the application of linguistic } \\
\text { programs }\end{array}$} \\
\hline \multicolumn{9}{|l|}{ Application of Instructions gained from the university } \\
\hline \multicolumn{9}{|l|}{ Application of information gained from the university } \\
\hline \multicolumn{9}{|l|}{ The impact of the teaching staff on a personal graduates } \\
\hline \multicolumn{9}{|l|}{ Ability to work within a team } \\
\hline \multicolumn{9}{|l|}{ The ability to self-development } \\
\hline The ability to innovate and development & & & & & & & & \\
\hline The ability to cope with the needs of the community & & & & & & & & \\
\hline
\end{tabular}

\section{Analysis of the of the Questionnaire about the Outcome} (graduate)

\section{Analysis}

Analysis of Questionnaire about the Outcome (the graduate)

\begin{tabular}{|l|l|}
\hline Is the levels of graduate & Pharmaceutical company \\
\cline { 2 - 2 } suitable for intended job & General pharmacy \\
\cline { 2 - 2 } & Hospital Pharmacy \\
\cline { 2 - 2 } & Pharmaceutical factory \\
\cline { 2 - 2 } & Drug store \\
\cline { 2 - 2 } & University Lecturer \\
\cline { 2 - 2 } & Insurance Companies \\
\hline
\end{tabular}

Are the levels of graduate suitable for intended job?

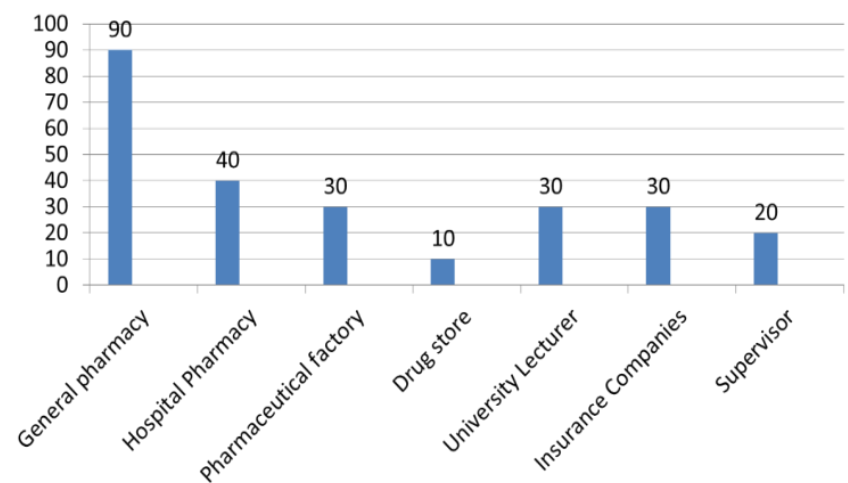

Analysis of Questionnaire about the Outcome (the graduate)

Apply the Graduate the Ethics Of the Pharmacy

Commitment and respect the graduates to their University

The level of graduates in language

Dealing with the computer and the application of linguistic programs

Application of Instructions gained from the university

Application of information gained from the university

The impact of the teaching staff on a personal graduates

Ability to work within a team

The ability to self-development

The ability to innovate and development

The ability to cope with the needs of the community

Volume 6 Issue 7, July 2017 www.ijsr.net

Licensed Under Creative Commons Attribution CC BY 


\section{International Journal of Science and Research (IJSR) \\ ISSN (Online): 2319-7064}

Index Copernicus Value (2015): 78.96 | Impact Factor (2015): 6.391

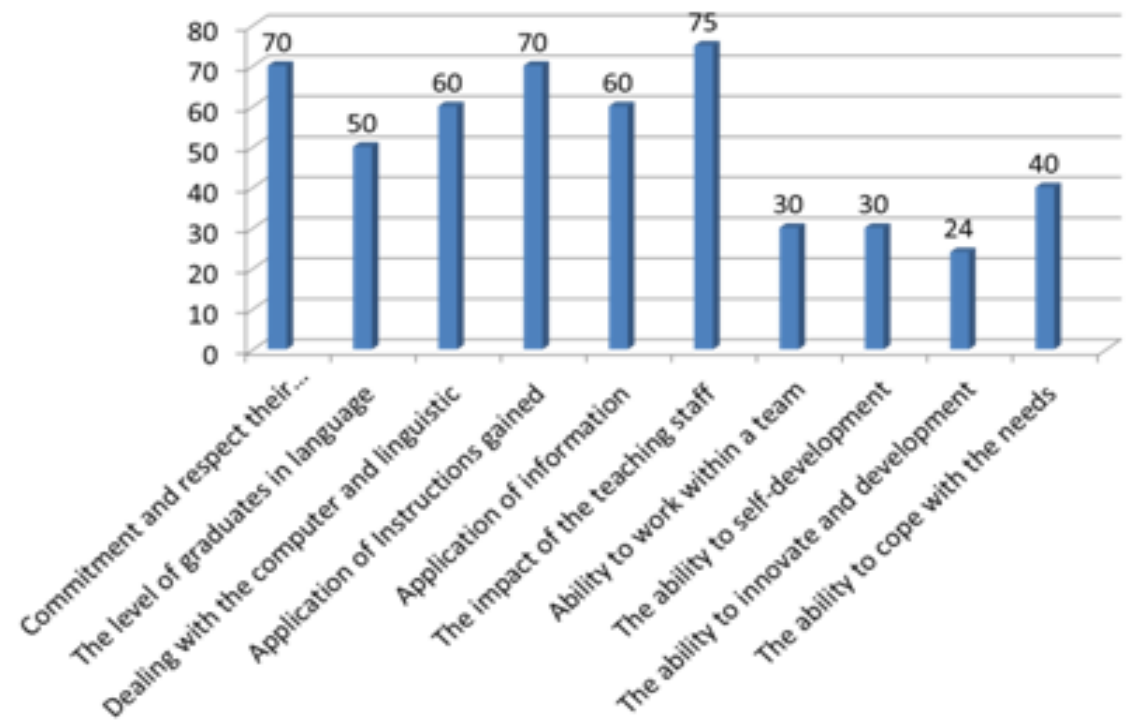

The Studied Subjects Syllabus in the Program of Pharmacy-SPU

\section{Analysis}

Analysis of Questionnaire about the Studied Subjects and Syllabus in the Program of Pharmacy-SPU
- are the Subjects cover all Syllabus

- are the subjects Cover the requirements

- Is the amount of the given information sufficient

- are the lectures long

- Is the syllabus adequate to the Program

- Modernization of the Syllabus

- Is the way to give the subjects suitable

- self-learning understanding the syllabus

- clarity the mission of the Subject

- Are the levels of the Subjects Suitable

- Are you satisfied with your Lecturer

- Are you convinced teachers

- Are you convinced the college management

Questionnaire about the Studied Subjects and Syllabus in the Program of Pharmacy-SPU
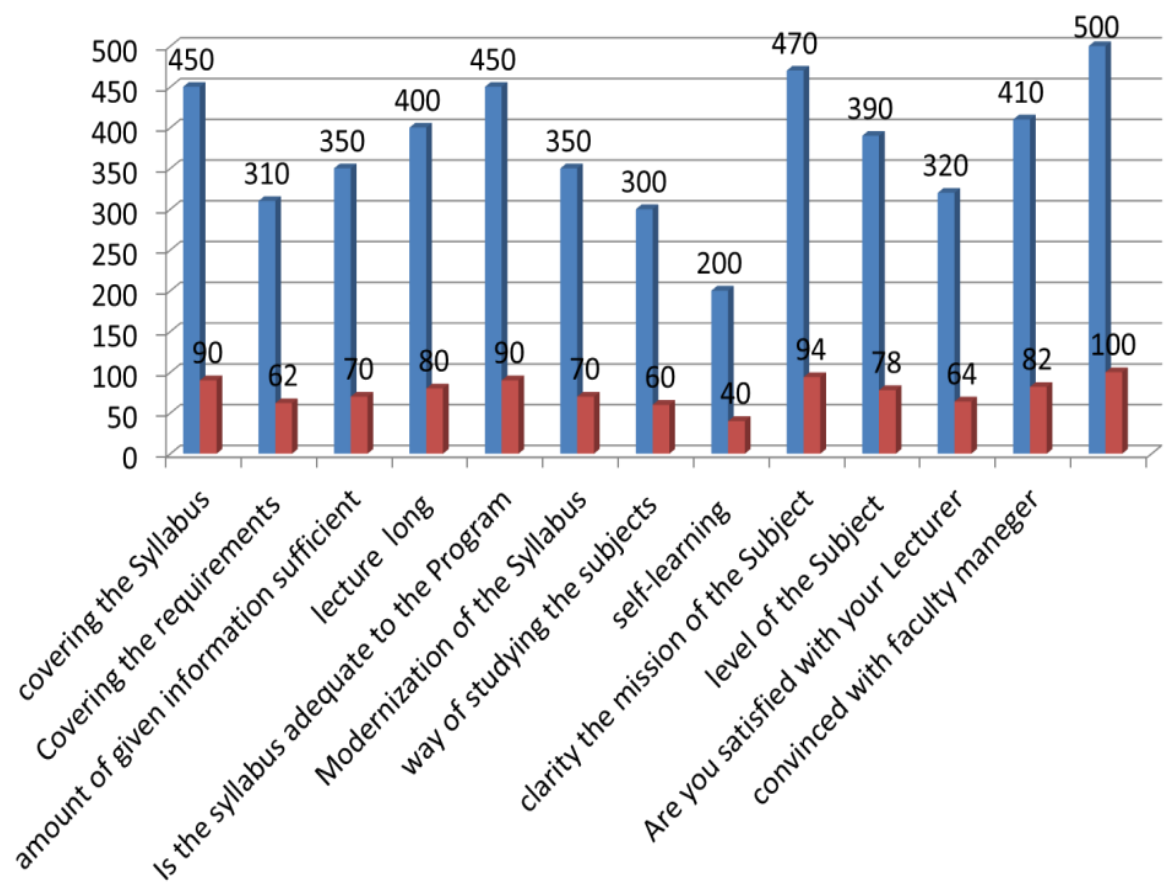

Volume 6 Issue 7, July 2017 www.ijsr.net 


\section{International Journal of Science and Research (IJSR) \\ ISSN (Online): 2319-7064 \\ Index Copernicus Value (2015): 78.96 | Impact Factor (2015): 6.391}

\section{Results and Discussion}

\section{Subjects Syllabus:}

From the Questionnaire it can be clearly seen that:

Most of Questionnaires are satisfied with the Syllabus and the Mission of the Subjects is clear. There is a Good relation between the intended Job and the studied Syllabus in the Program of pharmacySubjects Syllabus, There is a big gap in self-learning, what should be improved using seminaries lecture (references) and not to depend on lectures resumes, which hold by lectures.

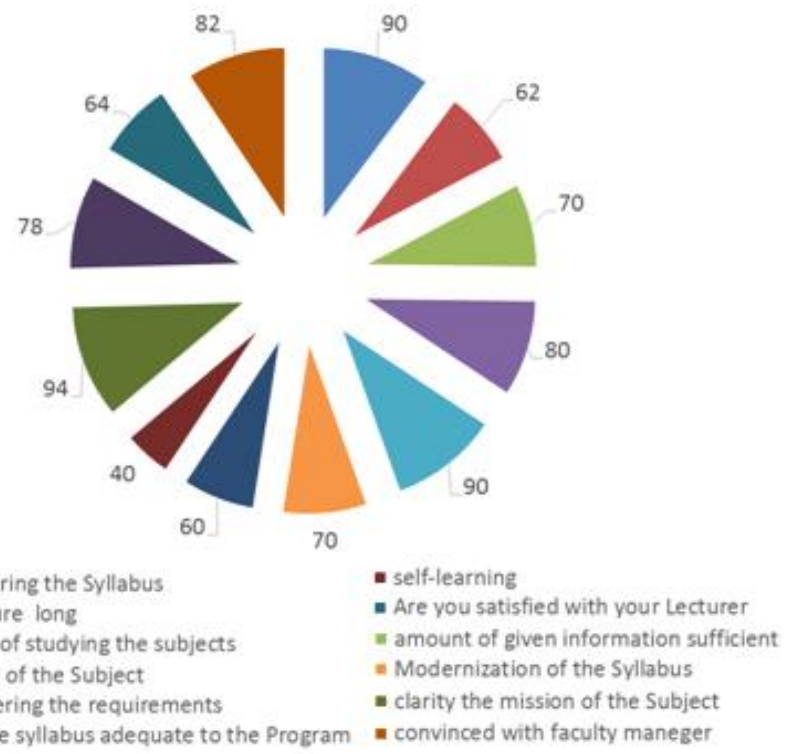

Suitability of Graduate for intended job

Most of graduate of the questionnaire want to work in General Pharmacy (Private), Other Work Branches are not well interested from the graduate of the questionnaire.

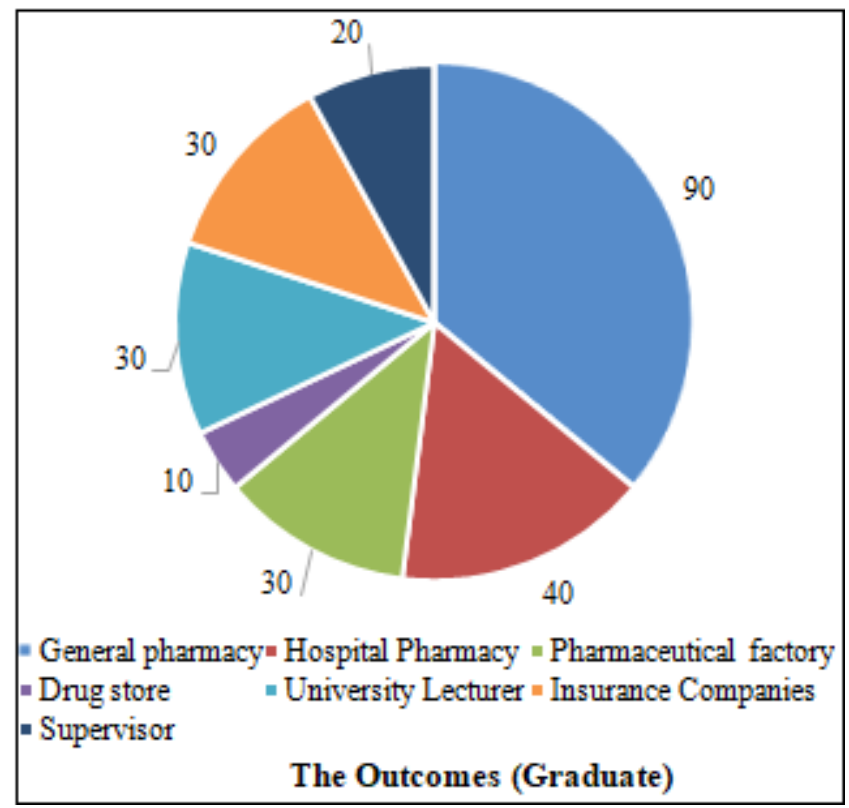

Most (80\%)of graduate of the questionnaire apply the ethics of pharmacy. Most $(75 \%)$ of graduate of the questionnaire respect the teachers and the university, Self-development and work in the team in addition to innovation all Of them was not very interested from the Graduate of the questionnaires.

\section{Resume}

External quality assurance criteria and processes used by the university: In Other Words from these research and others must be normally don in the assessment of the application Quality assurance in higher education using ; an external assessment by a group of experts, including, as appropriate, (a) student member(s), and site visits as decided by the university; a follow-up procedure to review actions taken by the subject of the quality assurance process in the light of any recommendations contained in the report.

\section{References}

[1] FIP Statement of Policy on Good Education Practice (2000) http://www.p.org/www2/uploads/database_le.php?id=18 8\&table_id= Accessed July 27, 2008

[2] The Tokyo Declaration (1993) Standards for quality of pharmacy services (FIP Guidelines for Good Pharmacy Practice, September 1993) and revised version FIP/WHO GPP (1997) http://www p.org/www2/uploads/database_le.php?id=261\&table_id= Accessed July 27, 2008

[3] FIP Statement of Professional Standards on Pharmaceutical Care (1998) http://www.p.org/www2/uploads/database_le.php?id=26 9\&table_id= Accessed July 27, 2008

[4] The Role of the Pharmacist in the Health Care System. Preparing the Future Pharmacist: Curriculum Development. Report of a Third World Health Organization Consultative Group on the Role of the Pharmacist. Vancouver, Canada 27-29 August 1997 http://www.who.int/medicinedocs/fr/d/Js2214e/\#Js2214e. 3.2 Accessed July 27, 2008

[5] The World Health Report 2006 - Working together for health http://www.who.int/whr/2006/en/ Accessed July 27, 2008

[6] European Association for Quality Assurance in Higher Education, 2009, Helsinki, 3rd edition

[7] The Syrian Higher education principals for Private universities 2015 